\title{
Towards a typology of video exercises
}

\section{Lesley Graham}

\section{(2) OpenEdition \\ Journals}

Electronic version

URL: http://journals.openedition.org/asp/3905

DOI: 10.4000/asp.3905

ISSN: 2108-6354

\section{Publisher}

Groupe d'étude et de recherche en anglais de spécialité

\section{Printed version}

Date of publication: 1 December 1995

Number of pages: 241-251

ISSN: 1246-8185

\section{Electronic reference}

Lesley Graham, «Towards a typology of video exercises », ASp [Online], 7-10 | 1995, Online since 30

October 2013, connection on 26 April 2019. URL : http://journals.openedition.org/asp/3905 ; DOI :

10.4000/asp.3905

This text was automatically generated on 26 April 2019.

Tous droits réservés 


\title{
Towards a typology of video exercises
}

\author{
Lesley Graham
}

1 The typology in question was created using Claris FileMaker Pro (the model card is reproduced in Appendix 1). It currently contains approximately 150 exercise types but it is anticipated that this number will rise to about 500 over the coming months as further exercises are defined and categorised.

2 The exercises included in this typology were for the most part designed to be used by students working autonomously. The reason for this being that a good part of my own experience in creating material to accompany video has been as a member of the VIFAX team in Bordeaux. ${ }^{1}$ However the vast majority of exercises can also be used in the classroom situation, or adapted for that situation. The exercises have usually been designed to accompany a self-contained report of the type presented in news bulletins and magazine programmes assuming no pre-existing knowledge of the subject matter and entailing no long character development. The excerpt is usually short, ideally between two and four minutes and certainly no longer than ten minutes. The typology does not include any indication of the learner level for which the exercise-type is intended since much depends on the point at which the exercise is introduced: on first, second, third, or subsequent viewings. The guiding principle has been that it is not so much the difficulty of the language used in the document itself as the complexity of the task that the learner is asked to accomplish while watching the video sequence that counts.

3 The exercise types included in the typology were all designed to be used in pre-viewing and viewing phases rather than after viewing when more elaborate language production might usefully be encouraged within the framework of follow-up activities. These exercises therefore concentrate on sensitising and comprehension. 


\section{Objectives}

4 exercises. There are two principal reasons: diversity and rapidity. We need to promote variety and creativity in the types of exercises offered to learners. It is important that learners using video regularly be offered variations on what might be called timehonoured EFL favourites, or equally well, the old chestnuts: True/ False and MCQ. The type of exercise offered must change to avoid passivity and routine. ${ }^{2}$ creation of comprehension exercises, another major concern when we're devising VIFAX exercises. Images date more quickly than sounds. Video documents generally have a relatively short shelf life and this is particularly true in ESP-last year's report on the latest scientific breakthrough is old hat today. The need to create new exercises to go with new video sequences is therefore great and the more quickly and efficiently this can be done the better. Material developers on whatever scale should find this sort of tool useful.

6 It is perhaps worth stressing at this point that we are in no way suggesting that set exercises can be made to fit whatever video excerpt. This typology is not an authoring program. On the contrary, the video material dictates the exercises that accompany it. There can be no question here of storing a few catch-all, set grids and questions in a computer and calling them up to go with whatever sequence. A given exercise type can, however, be used with vastly different video sequences and having those exercise types at one's fingertips is a very definite advantage. One may, for example, know that one wants learners to work on actions that appear in a news report, but can't think of an appropriate way of doing this. With the typology, one can call up a variety of exercisetypes that work on actions, choose from that selection, and adapt it to the given video sequence. Similarly, if you think your worksheet would benefit from a pre-viewing exercise but have run out of ideas, calling up a variety of examples may provide rapid inspiration.

\section{The categories}

7 Each exercise in the typology is given a title and it is classified in three menus: type, task, and topic.

\subsection{Type}

The first menu in this typology, called "type", separates the exercises into six broad categories depending on their type: Pre-focussing; Visual (i.e. non-verbal) comprehension; Comprehension 1; Comprehension 2; Comprehension 3; Language. There is obviously scope for overlap between these six categories but in most cases it is quite clear into which type the primary aim of a given exercise falls. 


\subsection{Pre-focussing}

9 For video, as with reading and listening the aim of a pre-focussing exercise is to create the desire to learn more about a given subject. The more we look forward to viewing, the more our curiosity has been aroused about what we are about to see, the easier it will be to grasp the main points of the video. In this type of exercise, questions are asked or suggested before the video is seen to make the viewers aware of what they know, what they don't know, what they want to know about the topic.

\subsection{Visual}

Since the visual element is the real trump card in video comprehension, the most should be made of it through exercises that encourage the learner to use the visual information to prepare the ground for language comprehension. These exercises are often designed to be completed with the sound down.

\subsection{Comprehension}

11 Most of us watch television in a passive (not to say vegetative) context. In a language learning situation this is simply not effective and so the exercises devised for video comprehension must encourage the learner to become a positive, responsive, participating viewer.

What makes video comprehension different from reading and listening comprehension? The most important and obvious difference is the visual element. Video is realia par excellence with an exploitable immediate impact on the viewer and more subtle clues about meaning that become evident only when the sequence is viewed several times. This visual element aids comprehension by rendering the information communicated immediate and dynamic. It complements the information communicated verbally with paralinguistic information: communication is shown in its entirety with accompanying activities, facial expressions, hand gestures. Comprehension is further facilitated by contextual clues, clothing, pointers in the surrounding environment, body language, which tell us about prevailing moods and relationships. The downside of the medium is that this vital visual information distracts from exercise completion. It is difficult, if not impossible to complete complex reading or writing tasks while watching the screen. Exercises to be completed simultaneously with watching must therefore be designed to keep the writing/reading load for the viewer to an absolute minimum.

13 The fundamental methodological principles of reading and listening comprehension hold for video. Most importantly, exercises should be designed to help language learners follow a video sequence rather than to test their comprehension of it. To promote this principle, Lonergan even avoids the expression "exercise" or "exercise sheet", and prefers "viewing guide" (Lonergan 1984: 11). Even more than with reading and listening the aim is not to check progress but to encourage progress; to reassure learners by giving them a framework around which to base their comprehension. This greater need for reassurance arises from the fact that the viewer is bombarded with language and visual information which, on first viewing, may well be overwhelming. The first exercise 
especially should be conceived of as a life belt; something that learners can hang on to and around which they can structure their initial comprehension.

Also, just as with listening, the basic skill is distinguishing from what is essential and what is peripheral and can therefore be ignored. Comprehension exercises should help the viewer to make this distinction.

Another basic principle derived from other media and which holds for video is the need for a series of exercises to progress from requiring general to specific information. In fact, with video this isn't so much a principle as a necessity: we may have to wean our students away from the habit of stopping and stumbling over unknown lexical items in a reading text; when watching a video they have no choice since the word they don't recognise, or the sentence they can't quite catch flashes past and is gone in a moment. A typical three/four minute video sequence might be accompanied by three or four comprehension exercises, which might be preceded by a pre-focussing pre-viewing exercise. These exercises should evolve from asking for the most general information from, or even impression of the sequence, to asking for more detailed information. This progression is reflected in the numbering of the three comprehension categories in our typology:

Comprehension 1: very general

Comprehension 2: more specific

Comprehension 3: specific

And again as with listening, the tapescript of any video sequence used should always be provided for the learner. Many, perhaps most, video sequences originate in a written script and it is logical to complete the cycle by going back to that script after completing the comprehension exercises. This allows the learner to understand and analyse the comprehension strategies he or she called upon (or perhaps failed to call upon) in attempting to complete the exercises.

\subsection{Language}

With video "the language work is part of a process that is wider and more interesting than itself" (Cooper 1991: 7) which can be a highly motivating factor for learners of a nonlinguistic bent. Language -learning takes place not within a void but is located within and connected to the material that it exploits: it is contextualised. Logically, the language exercise should come last on the worksheet. These language exercises could really be the subject of a separate typology, however, in cases where the language exercise-type continues the comprehension process, it has been included in this typology.

\section{The Tasks}

The second menu in the typology lists the tasks that the viewer may be asked to complete in any exercise. In all of these exercises what the viewer is asked to do on paper is extremely limited; production is kept to a minimum. We must take into account the fact that in the early stages, i.e. on first, second, third viewing, the learner's eyes are almost fully taken up with watching the screen. This means firstly, that it is extremely important that the learner should be encouraged to read through all of the tasks on the worksheet before actually watching the video sequence, and secondly that those tasks should leave his/her eyes as free as possible to follow what is happening on screen. Note taking 
exercises should be kept for the third or fourth viewing when the learner's eyes can wander from the screen without risking missing some essential clue. The "task" menu specifies what the actual task involves. The following table lists the possibilities in (more or less) ascending order of the amount of production required. Obviously the nonlinguistic activities are easiest.

Table 1: List of tasks

\begin{tabular}{|c|c|}
\hline TASK & \\
\hline think & $\begin{array}{l}\text { Doesn't involve any writing. Simply asks learners to think about what they } \\
\text { already know about a subject or their opinion on a subject, usually before viewing } \\
\text { as a pre-focussing exercise. }\end{array}$ \\
\hline match & $\begin{array}{l}\text { This usually involves drawing a line between two columns, but viewers can also } \\
\text { be asked to match information to pictures or drawings, graphs or charts. }\end{array}$ \\
\hline $\begin{array}{l}\text { select } \\
\text { options }\end{array}$ & $\begin{array}{l}\text { This involves selecting either the correct option in a range of options or the odd } \\
\text { option out. Learners can be asked to indicate their selection in a variety of ways: } \\
\text { underlining, ticking, marking with a cross, circling, scoring out.... Obviously } \\
\text { restricting the number of options makes the task more manageable. }\end{array}$ \\
\hline $\begin{array}{l}\text { write true/ } \\
\text { false }\end{array}$ & $\begin{array}{l}\text { Needs no introduction. Variations on the theme include introducing (T/F) } \\
\text { statement that are neither true nor false but about which there is no information } \\
\text { in the video. }\end{array}$ \\
\hline gap-fill & $\begin{array}{l}\text { Learners can be asked to provide the missing words in a summary report, } \\
\text { sentences taken from the video etc. }\end{array}$ \\
\hline draw & $\begin{array}{l}\text { Learners are asked to represent information in the video in a drawing or a } \\
\text { diagram. }\end{array}$ \\
\hline order & $\begin{array}{l}\text { Usually involves ordering events chronologically with reference to real time by } \\
\text { putting numbers next to a list of events, but students can also be asked to } \\
\text { sequence events, information or scenes according to the order in which they are } \\
\text { mentioned/seen in the video }{ }^{3} \text {. }\end{array}$ \\
\hline correct & Here deliberately erroneous statements must be rectified. \\
\hline label & $\begin{array}{l}\text { Viewers are provided with a drawing which they are asked to label using } \\
\text { vocabulary and information from the video. }\end{array}$ \\
\hline crossword & $\begin{array}{l}\text { Learners are asked to find words from the video that correspond to clues given } \\
\text { and put the words into a crossword. }\end{array}$ \\
\hline sort & $\begin{array}{l}\text { Learners are provided with a list of vocabulary which must be sorted into } \\
\text { categories / organised into a network. }\end{array}$ \\
\hline
\end{tabular}




\begin{tabular}{|c|c|}
\hline fill in & $\begin{array}{l}\text { This involves filling in a table or a "dossier" with information from the sequence. } \\
\text { Can be made as realistic as possible. Helps learners to concentrate on the main } \\
\text { information contained in the video and to ignore the rest by encouraging } \\
\text { selective extraction of the points needed to fill in the table. Structures the } \\
\text { students viewing. }\end{array}$ \\
\hline replace & $\begin{array}{l}\text { Asks viewers to replace words/expressions in sentences from the video with } \\
\text { simpler expressions: a roundabout way of providing synonymous expressions for } \\
\text { vocabulary that might impede comprehension. }\end{array}$ \\
\hline $\begin{array}{l}\text { complete } \\
\text { sentences }\end{array}$ & $\begin{array}{l}\text { Asks learners to finish the beginnings of sentences either taken directly from the } \\
\text { video or, more usually, forming a summary paragraph. }\end{array}$ \\
\hline $\begin{array}{l}\text { write } \\
\text { answers }\end{array}$ & $\begin{array}{l}\text { Often presents the viewer with an imaginary interview with one of the characters } \\
\text { in the video, asks the viewer to provide answers to the interviewers' questions. }\end{array}$ \\
\hline $\begin{array}{l}\text { write } \\
\text { questions }\end{array}$ & $\begin{array}{l}\text { Provides answers to questions that might be asked about information in the } \\
\text { video, asks the learners to formulate the questions that would elicit these } \\
\text { answers }\end{array}$ \\
\hline
\end{tabular}

\section{Topics}

The third and final way in which the exercises are categorised in this typology is according to their topic, that is the aspect of the video sequence that they exploit and work on rather than the actual subject matter of the video excerpt. Here again there is scope for overlap but it is not usually too difficult to decide on the main aspect of a video that any given exercise concentrates on.

\section{Table 2: List of topics}

\begin{tabular}{|l|l|}
\hline TOPIC & \\
\hline $\begin{array}{l}\text { general } \\
\text { impression }\end{array}$ & $\begin{array}{l}\text { Asks learners to formulate a general idea about what the excerpt is or } \\
\text { might be about. Often to be completed with sound down. }\end{array}$ \\
\hline image & $\begin{array}{l}\text { Draws attention to what is actually seen on screen rather than what is } \\
\text { heard. }\end{array}$ \\
\hline $\begin{array}{l}\text { general } \\
\text { understanding }\end{array}$ & $\begin{array}{l}\text { Helps viewers to tease out the main thrust of the sequence, usually on first } \\
\text { viewing. }\end{array}$ \\
\hline $\begin{array}{l}\text { link } \\
\text { image and words }\end{array}$ & $\begin{array}{l}\text { Works on the relationship between the soundtrack and the pictures, by e.g. } \\
\text { asking for visual evidence to support statements heard. }\end{array}$ \\
\hline general concepts & Promotes the understanding of general concepts communicated. \\
\hline $\begin{array}{l}\text { factual } \\
\text { information }\end{array}$ & \begin{tabular}{l} 
Works on the main factual content of a sequence \\
\hline
\end{tabular}
\end{tabular}




\begin{tabular}{|l|l|}
\hline structure & $\begin{array}{l}\text { These exercises are designed to help the viewer to visualise the } \\
\text { organisation of the whole sequence. Rather like matching paragraphs in a } \\
\text { text with headings, asks learners to identify the functions of the passages } \\
\text { that make up a sequence. Promotes critical video literacy. }\end{array}$ \\
\hline opinion & Asks learners to identify and/or interpret opinions expressed. \\
\hline process & Highlights the steps that make up a process described or seen on screen. \\
\hline discrete points & Asks for precise information in the form of words. \\
\hline numbers & Asks for precise information in the form of figures. \\
\hline chronology & $\begin{array}{l}\text { Asks the learner to recreate chronological order using information in the } \\
\text { sequence, usually by concentrating on time markers. }\end{array}$ \\
\hline inference & $\begin{array}{l}\text { Usually asks learners to match definitions with expressions used in the } \\
\text { sequence. A roundabout way of allowing learners to see difficult lexical } \\
\text { items. }\end{array}$ \\
\hline gocabulary & Works on interpreting emotions communicated physically or verbally. \\
\hline emotions & Works on what we see people and things actually do on screen. \\
\hline stated.
\end{tabular}

\section{Conclusion}

20 To conclude, I would like to draw attention to the word "towards" in my title. This is a vast subject and no doubt, in time, the "task" and "topic" menus in this typology will be, lengthened and/or honed. ${ }^{4}$ The typology has proved useful in providing a bank of exercise ideas and formats that can be readily adapted to suit new video sequences. The whole process of defining and categorising these exercises has been just as useful in that it has led to much reflection on the ways in which the exercise mediates between the video sequence and the learner and on the most effective ways in which we can help the active viewer penetrate and comprehend those sequences. 


\section{BIBLIOGRAPHY}

Attal, J.-P., M. Mémet and J. Schlissinger (eds.). 1991. Nouvelles Technologies et enseignement des langues. Paris: TILV.

Cooper, R., M. Lavery and M. Rinvolucri. 1991. Video, Resource Books for Teachers. Oxford: Oxford University Press.

Grellet, F. 1981. Developing Reading Skills: a Practical Guide to Reading Comprehension Exercises. Cambridge: Cambridge University Press.

Lonergan, J. 1984. Video in Language Teaching, New Directions In Language Teaching. Cambridge: Cambridge University Press.

Perrin, M. 1993. "La Formation multimédia à distance en autonomie guidée à quelles conditions ?". In Attal et al., Nouvelles technologies et enseignement des langues. Paris: TILV.

Perrin, M. 1991. “Wherefore VIFAX ?”. The European English Messenger 1/1.

\section{APPENDIXES}

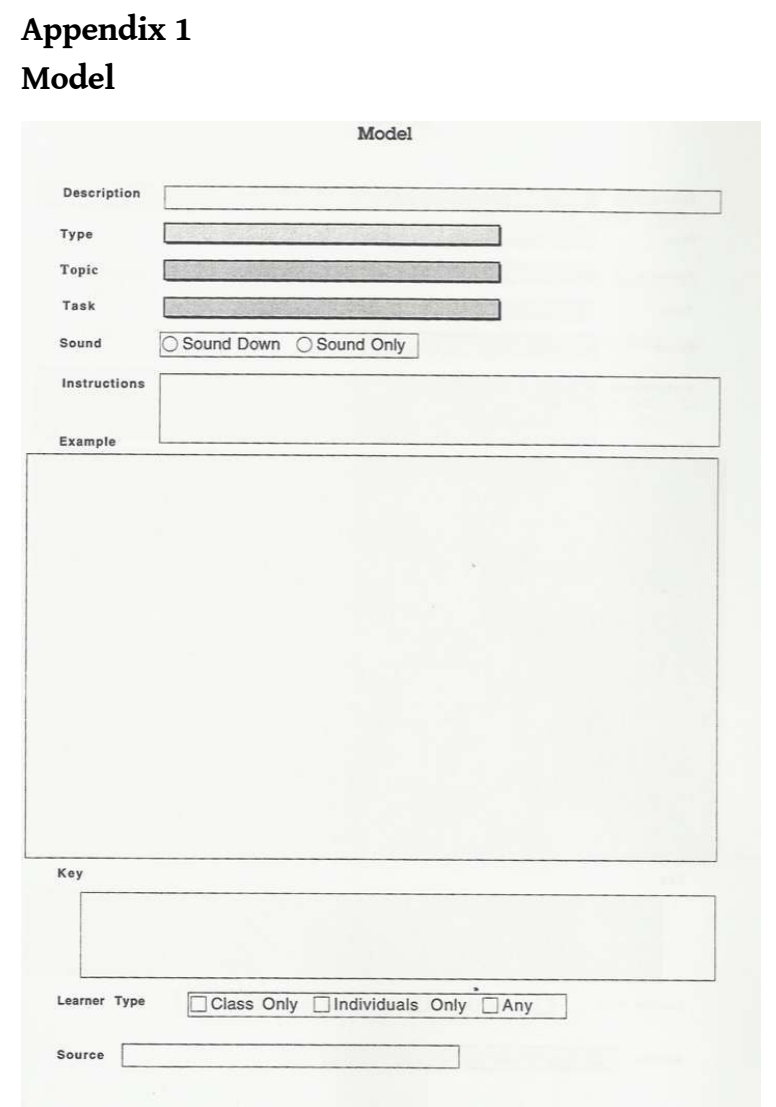

\section{Appendix 2 \\ Example}




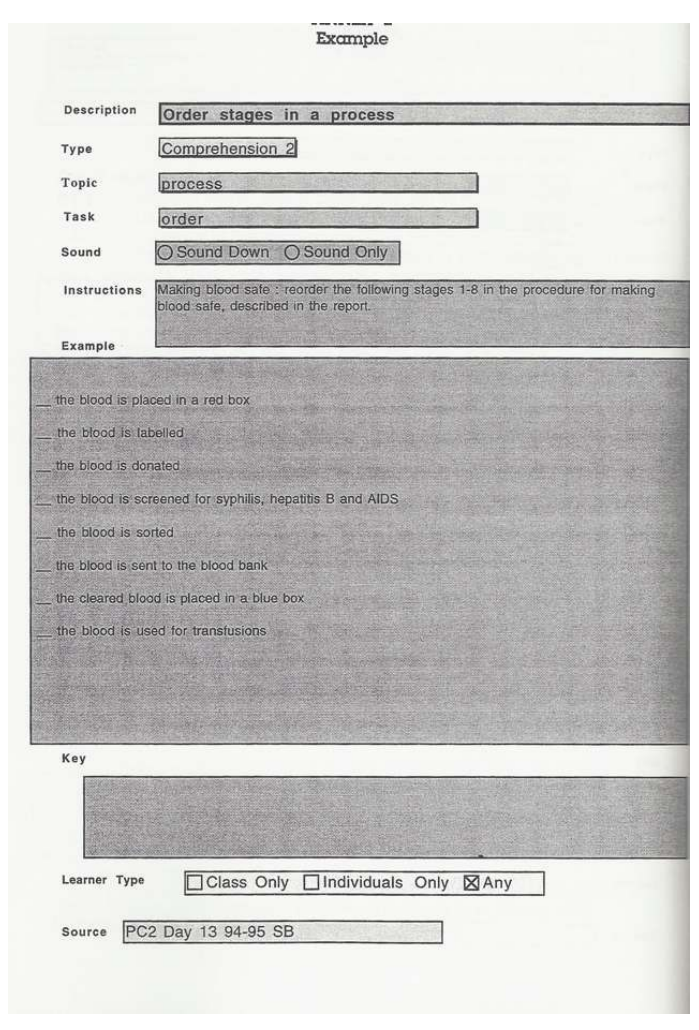

\section{NOTES}

1. For a description of VIFAX cf. M. Perrin, 1991, 1993.

2. This is especially true for VIFAX which is sent out to subscribers 120 days a year with two worksheets every day comprising an average of four exercises each -960 exercises a year.

3. A commonly raised objection to this type of exercise is that if the learner gets one event out of order then all of the subsequent events will be out of order. This may be a valid argument against using this type of task in an exam or a test, but here we are concerned with exercises that aid and structure comprehension. The learner is perfectly capable of understanding the cumulative effect of one mistake and taking that into account when assessing his/her comprehension. Here again, obviously the fewer events there are to put back in order the lighter the load for simultaneous viewing.

4. The typology, as it stands, is available on diskette (Macintosh, Claris FileMaker Pro) from L. Graham, DLVP, Université de Bordeaux 2, 3 place de la Victoire, 33076 Bordeaux Cedex.

\section{ABSTRACTS}

The effective use of video in language teaching must always involve more than simply replaying a television programme and eliciting learner reaction. Language learners must be active while they watch hence the need for didactic mediation in the form of varied, thought-provoking, helpful, effective support materials that exploit the raw video document. This paper and the 
typology it describes attempt to define and categorise the various exercise types suitable for video support materials. The typology draws on the bank of exercises and the experience gained by the team at the DLVP Bordeaux 2 in didactising news reports for VIFAX over the past five years.

L'utilisation de la vidéo à bon escient dans un cours de langue doit toujours dépasser le simple visionnement d'une séquence vidéo en suscitant des réactions de la part des apprenants. Ces derniers doivent, en effet, être actifs lorsqu'ils regardent d'où le besoin d'une médiation didactique en forme d'exercices utiles, efficaces et intelligents exploitant le document brut. Cet article, ainsi que la typologie qu'il décrit, tente de définir et de catégoriser les différents types d'exercices susceptibles d'accompagner une séquence vidéo. La typologie a pour origine l'importante banque d'exercices et l'expérience de l'équipe du DLVP, Bordeaux 2 dans la didactisation des informations pour VIFAX au cours des cinq dernières années.

INDEX

Mots-clés: compréhension, didactisation, exercice, typologie, vidéo

Keywords: didactisation, exercise, video, typology, material

\section{AUTHOR}

\section{LESLEY GRAHAM}

Lesley Graham teaches at Université Bordeaux 2. Lesley.Graham@lv.u-bordeaux2.fr 